\title{
PENGARUH STERILISASI OZON TERHADAP PENURUNAN ANGKA KUMAN UDARA DI RUANG RAWAT INAP DI RUMAH SAKIT UMUM PKU MUHAMMADIYAH BANTUL 2014
}

\author{
Liena Sofiana, Dwi Wahyuni \\ Fakultas Kesehatan Masyarakat, Universitas Ahmad Dahlan, Yogyakarta \\ Email: liena.sofiana@ikm.uad.ac.id
}

\begin{abstract}
Background: Nosocomial infections are infections that are acquired from hospital that when the patient is in the process of care after \pm 72 hours. In order to minimize cases of nosocomial infection need control from hospital. Control of nosocomial infections in hospitals include prevention and control activities. To reduce the occurrence of nosocomial infections need to take measures eliminate disease-causing germs from the source of infection, preventing the bacteria reach the patient and keep vulnerable patients. The most important factor is hygiene and personal hygiene as well as hospitals, one of which is to perform decontamination and sterilization treatment rooms. The purpose of the study was to determine the effect of ozone sterilization of the air germ reduction in inpatient in PKU Muhammadiyah Hospital in Bantul.

Methods: This study used design of experiments (one group pre and post test design), with a number of research subjects, namely air germs in PKU Muhammadiyah Bantul. Data were analyzed used paired sample t-test.

Result: no effect between ozone sterilization to decrease number of bacteriain the airspace at the inpatient unit in PKU Muhammadiyah Hospital in Bantul with p value 0,051 (Cl 95\% = 0,10132,545).

Conclusion: there is no effect between ozone sterilization to decrease number of bacteria in the air space at the inpatient unit in PKU Muhammadiyah Bantul 2014.
\end{abstract}

Keywords: ozone sterilizer, air germ rate, inpatient unit

\begin{abstract}
Abstrak
Latar belakang: Infeksi nosokomial adalah infeksi yang diperoleh dari rumah sakit yaitu infeksi yang didapat ketika pasien sedang dalam proses perawatan setelah \pm 72 jam. Untuk meminimal kasus infeksi nosokomial perlu dilakukan pengendalian. Pengendalian infeksi nosokomial di rumah sakit meliputi kegiatan pencegahan dan penanggulangan. Untuk mengurangi terjadinya infeksi nosokomial perlu dilakukan langkah-langkah menghilangkan kuman penyebab penyakit dari sumber infeksi, mencegah kuman tersebut mencapai penderita dan menjauhkan penderita yang rentan. Faktor yang paling penting adalah higiene dan kebersihan perorangan maupun rumah sakit, salah satunya adalah dengan melakukan dekontaminasi dan sterilisasi ruang perawatan. Tujuan penelitian adalah untuk mengetahui pengaruh sterilisasi ozon terhadap penurunan angka kuman udara di ruang rawat inap Rumah Sakit Umum PKU Muhammadiyah Bantul.
\end{abstract}

Metode: Penelitian ini dengan menggunakan eksperimen dengan rancangan Ulang (one group pre and post test design), dengan subjek penelitian yaitu angka kuman udara di ruang rawat inap RSU PKU Muhammadiyah Bantul. Analisis data menggunakan uji statistik yaitu paired sample t-test.

Hasil: tidak ada pengaruh antara sterilisasi ozon terhadap penurunan angka kuman udara di ruang rawat inap di RSU PKU Muhammadiyah Bantul dengan pvalue 0,051 (Cl 95\% = 0,10132,545).

Kesimpulan: tidak ada pengaruh antara sterilisasi ozon terhadap penurunan angka kuman udara di ruang rawat inap di RSU PKU Muhammadiyah Bantul 2014.

Kata Kunci: sterilisasi ozon, angka kuman udara, ruang rawat inap 


\section{Pendahuluan}

Rumah sakit adalah institusi pelayanan kesehatan yang menyelenggarakan pelayanan kesehatan perorangan secara paripurna yang menyediakan pelayanan rawat inap, rawat jalan dan gawat darurat. ${ }^{1}$ Rumah sakit merupakan suatu organisasi yang bergerak di bidang pelayanan kesehatan yang sangat diperlukan dalam mendukung penyelenggaraan upaya kesehatan. Penyelenggaraan pelayanan kesehatan di rumah sakit mempunyai karakteristik yang sangat kompleks. Kompleksitas permasalahannya tidak hanya dari segi jenis dan macam penyakit tetapi juga dari sejumlah orang yang berada di rumah sakit baik berinteraksi langsung maupun tidak langsung dengan pasien yang dirawat di rumah sakit. Keadaan ini akan mempermudah terjadinya penularan penyakit infeksi silang baik dari pasien ke pasien maupun antar pasien dengan tenaga kesehatan di rumah sakit. Terkadang penyakit yang semula hanya ada satu penyebab penyakit, justru di rumah sakit tersebut seorang pasien bisa mendapatkan berbagai penyakit lain dikarenakan infeksi yang didapatkan dari rumah sakit atau biasa disebut infeksi nosokomial. ${ }^{2}$

Penderita yang sedang dalam proses asuhan perawatan di rumah sakit, baik dengan penyakit dasar tunggal maupun penderita dengan penyakit dasar lebih dari satu, secara umum keadaan umumnya tentu tidak/kurang baik, sehingga daya tahan tubuhnya menurun. Hal ini akan mempermudah terjadinya infeksi silang karena kuman-kuman, virus, dan sebagainya akan masuk ke dalam tubuh penderita yang sedang dalam proses asuhan keperawatan dengan mudah. Infeksi yang terjadi pada penderita-penderita yang sedang dalam proses asuhan keperawatan ini disebut infeksi nosokomial. ${ }^{2}$ Suatu standar minimal pelayanan rumah sakit, termasuk didalamnya pelaporan kasus infeksi nosokomial untuk melihat sejauh mana rumah sakit melakukan pengendalian terhadap infeksi ini. Data infeksi nosokomial dari surveilans infeksi nosokomial di setiap rumah sakit dapat digunakan sebagai acuan pencegahan infeksi guna meningkatkan pelayanan medis bagi pasien. ${ }^{3}$

Insiden kejadian penyakit infeksi merupakan yang tertinggi di Indonesia. Di samping itu infeksi nosokomial sering menimbulkan kematian, memperpanjang waktu rawat nginap, menambah beban penderita dengan biaya tambahan untuk perawatan clan pengobatan pasien. Infeksi nosokomial banyak terjadi di seluruh dunia dengan kejadian terbanyak di negara miskin dan negara yang sedang berkembang karena penyakit-penyakit infeksi masih menjadi penyebab utama. Suatu penelitian yang yang dilakukan oleh WHO menunjukkan bahwa sekitar 8,7\% dari 55 rumah sakit dari 14 negara yang berasal dari Eropa, Timur Tengah, Asia Tenggara dan Pasifik tetap menunjukkan adanya infeksi nosokomial dengan Asia Tenggara sebanyak $10 \%{ }^{4}$

Perkembangan ilmu mikrobiologi telah memberikan sumbangan yang besaar bagi dunia kesehatan, dengan ditemukannya berbagai macam alat berkat penemuan beberapa ilmuan besar. Bahwa terbukti untuk mencegah atau mengendalikan infeksi tenaga kesehatan dapat menggunakan konsep steril ataupun bersih, untuk membantu proses penyembuhan pasiennya dan lebih spesifik lagi untuk mengendalikan dan mencegah terjadinya infeksi. Walaupun ilmu pengetahuan dan penelitian tentang mikrobiologi meningkat dengan pesat pada tiga dekade terakhir serta sedikit demi sedikit resiko infeksi dapat dicegah, tetapi semakin meningkatnya pasien-pasien dengan penyakit immunocompromised, bakteri yang resisten antibiotik, super infeksi virus dan jamur, dan prosedur invasif, masih menyebabkan infeksi nosokomial menimbulkan kematian sebanyak 88.000 kasus setiap tahun. Selain itu, jika kita bandingkan kuman yang ada di masyarakat, mikroorganisme yang berada di rumah sakit lebih berbahaya dan lebih resisten terhadap obat, karena diperlukan antibiotik yang lebih poten atau suatu kombinasi antibiotik. Semua kondisi ini dapat meningkatkan resiko infeksi kepada si pasien. ${ }^{4}$

Salah satu upaya untuk mengontrol pertumbuhan mikroorganisme di rumah sakit adalah kegiatan desinfeksi dan sterilisasi. Sterilisasi adalah proses pengolahan

KESMAS Vol. 9, No. 1, Maret 2015: $19-24$ 
suatu alat atau bahan dengan tujuan mematikan semua mikroorganisme termasuk endospore pada suatu alat atau bahan. Teknik sterilisasi ruangan ada beberapa metode diantaranya adalah penyinaran, penyaringan dan sterilisasi dengan bahan kimia atau gas. Sterilisasi ruangan di ruang operasi pada umumnya menggunakan sinar ultraviolet dan bahan kimia atau desinfektan. ${ }^{5}$

Rumah Sakit PKU Muhammadiyah Bantul sebagai tempat rujukan di daerah, berfungsi menyelenggarakan upaya kesehatan yang bersifat penyembuhan dan pemulihan pasien. Bukan sebaliknya menambah jumlah orang sakit karena terjadinya infeksi nosokomial. Oleh karena itu peneliti tertarik untuk meneliti pengaruh sterilisasi ozon terhadap penurunan angka kuman udara di ruang rawat inap di Rumah Sakit Umum PKU Muhammadiyah Bantul 2014.

\section{Metode Penelitian}

Jenis penelitian adalah penelitian eksperimen (one group pre and post test design). Pretest angka kuman sebelum dilakukan sterilisasi dengan ozon sedangkan post test adalah angka kuman sesudah dilakukan sterilisasi ozon. Penelitian ini dilakukan di ruang rawat inap Rumah Sakit Umum PKU Muhammadiyah Bantul pada bulan Juli 2014. Pengambilan sampel kuman udara dengan (Midget impinge dan air pump) dan diperiksa di laboratorium dengan metode pour plate. Data yang sudah terkumpul kemudian dilakukan analisis data dengan Uji T berpasangan (paired t-test).

\section{Hasil Penelitian dan Pembahasan}

\section{A. Hasil Penelitian}

Analisis univariat untuk menunjukkan gambaran penelitian secara deskriptif. Gambaran objek penelitian berdasarkan sterilisasi yang dilakukan di ruang rawat inap, secara lengkap tersaji pada Tabel 1 berikut:

Tabel 1. Ruang rawat inap yang dilakukan sterilisasi ozon di RSU PKUMuhammadiyah Bantul 2014

\begin{tabular}{clc}
\hline No & \multicolumn{1}{c}{ Nama ruang } & Jenis kelas \\
\hline 1 & Ar rahman 1 & \\
2 & Ar rahman 2 & Kelas 1 \\
3 & Al kahfi 1 & \\
4 & An nisa 4 & Kelas 2 \\
5 & Ar rahman 9 & \\
6 & Al insan 8 & \\
7 & Ar rahman 17 & Kelas 3 \\
8 & Al a'raf 18 & \\
9 & Al a'raf 19 & \\
\hline
\end{tabular}

Tabel 1 menunjukkan bahwa sterilisasi ozon yang dilakukan di ruang rawat inap di RSU PKU Muhammadiyah Bantul hanya di kelas 1, 2 dan 3 dengan metode sampel saja. Hal ini dikarenakan lokasi ruang harus dalam keadaan tidak ada pasien di ruangan tersebut.

Gambaran hasil perhitungan setelah dilakukan sterilisasi ozon di beberapa ruang rawat inap di RSU PKU Muhammadiyah Bantul secara lengkap tersaji dalam Tabel 2 berikut: 
Tabel 2. Hasil perhitungan angka kuman dengan sterilisasi ozon pre dan post di ruang rawat inap di RSU PKU Muhammadiyah Bantul 2014

\begin{tabular}{lcccc}
\hline \multirow{2}{*}{ Nama ruang } & Kelas & \multicolumn{2}{c}{$\begin{array}{c}\text { Perhitungan angka kuman } \\
\left(\mathrm{CFU} / \mathrm{m}^{3}\right)\end{array}$} & $\begin{array}{c}\text { Selisih perhitungan } \\
\text { angka kuman } \\
\left(\mathrm{CFU} / \mathrm{m}^{3}\right)\end{array}$ \\
\cline { 3 - 4 } & & Pre & Post & 6 \\
\hline Ar rahman 1 & Kelas 1 & 110 & 27 & 6 \\
Ar rahman 2 & & 45 & 104 & 12 \\
Al kahfi 1 & 120 & 33 & 2 \\
An nisa 4 & Kelas 2 & 184 & 118 & 69 \\
Ar rahman 9 & & 86 & 115 & 12 \\
Al insan 8 & & 177 & 166 & 11 \\
Ar rahman 17 & Kelas 3 & 131 & 104 & 27 \\
Al a'raf 18 & & 93 & 92 & 1 \\
Al a'raf 19 & & & & \\
\hline
\end{tabular}

Tabel 2 menunjukkan bahwa selisih penurunan angka kuman udara sebelum dan sesudah dilakukan sterilisasi ozon yang paling tinggi penurunannya adalah di ruang Ar rahman 9 sebesar $69 \mathrm{CFU} / \mathrm{m}^{3}$ sedangkan penurunan angka kuman terendah adalah di ruang Al a'raf 19 sebesar $1 \mathrm{CFU} / \mathrm{m}^{3}$.

Analisis bivariat dilakukan untuk mengetahui pengaruh sterilisasi ozon terhadap penurunan angka kuman udara di ruan rawat inap di RSU PKU Muhammadiyah Bantul. Hasil analisis tersaji secara lengkap pada Tabel 3 berikut:

Tabel 3. Pengaruh sterilisasi ozon terhadap penurunan angka kuman udara di ruang rawat inap di RSU PKU Muhammadiyah Bantul 2014

\begin{tabular}{lccccc}
\hline Sterilisasi ozon & $\mathrm{n}$ & Rerata \pm s.d & $\begin{array}{c}\text { Perbedaan } \\
\text { rerata } \pm \text { s.d }\end{array}$ & IK 95\% & Sig \\
\hline $\begin{array}{l}\text { Angka kuman sebelum } \\
\text { sterilisasi ozon }\end{array}$ & 9 & $108,78 \pm 51,88$ & $16,22 \pm 21,23$ & $0,101-$ & 0,051 \\
Angka kuman sesudah & 9 & $92,56 \pm 43,29$ & & 32,545 &
\end{tabular}

sterilisasi ozon

Tabel 3 diatas menunjukkan bahwa berdasarkan uji statistik tidak ada pengaruh antara sterilisasi ozon terhadap penurunan angka kuman udara di ruang rawat inap di RSU PKU Muhammadiyah Bantul dengan $P$ value 0,051. Interval kepercayaan (IK) dilakukan pada ruang rawat inap, selisih angka kuman udara sebelum dilakukan sterilisasi ozon dengan angka kuman udara sesudah sterilisasi ozon adalah antara 0,101 sampai 32,545.

\section{B. Pembahasan}

Berdasarkan hasil statistik dapat dikatakan bahwa tidak ada pengaruh sterilisasi ozon dengan penurunan angka kuman udara di ruang rawat inap di RSU PKU Muhammadiyah Bantul, sehingga dapat dikatakan bahwa sterilisasi ozon tidak efektif dalam penurunan angka kuman udara ruangan. Tidak adanya pengaruh sterilisasi ozon terhadap penurunan angka kuman ruang rawat inap secara statistik, dapat disebabkan oleh kesalahan dalam pengambilan sampel penelitian yaitu sedikitnya ruangan yang dijadikan sebagai sampel dalam proses sterilisasi. Sedikitnya jumlah ruangan yang dilakukan sterilisasi karena dalam proses sterilisasi harus dalam keadaan kosong tanpa pasien sehingga ini merupakan keterbatasan dalam penelitian ini. 
Selain disebabkan oleh jumlah sampel yang sedikit, factor lain yang menyebabkan bahwa ozon tidak berpengaruh adalah mobilitas orang ketika pengujian sterilisasi di ruangan tersebut. Hasil tersebut didukung oleh penelitian lain bahwa sterilisasi alat ozon tidak mampu membubuh Bacillus subtilis pada jarum dikarenakan peralatan disterilisasikan dalam kondisi tertutup, ozon sendiri dalam bekerjanya memerlukan kontak langsung dengan bakteri. Dalam keadaan tertutup, ozon yang merupakan gas dingin tidak mampu menembus tabung sehingga sterilisasi tidak terjadi. ${ }^{6}$

Sterilisasi ozon cocok untuk instrument stainless steel, namun ada beberapa terbatas pada alat-alat yang berrongga, selain itu ozon juga sangat efektif terhadap macam-macam mikroorganisme pada buah-buahan dan sayuran. ${ }^{7}$ Metode sterilisasi ozon merupakan teknologi yang paling unggul dan sangat efektif. Ozon dapat menghancurkan kuman, bakteri, virus, jamur, spora, kista, lumut dan zat organik lainnya. ${ }^{8}$ Penggunaan ozon tidak menghasilkan zat sisa yang membahayakan kesehatan, bahkan sebaliknya akan menambahkan kadar oksigen dalam air. ${ }^{9}$

Selain efektif dalam penurunan mikroorganisme pada alat-alat kesehatan, buah-buahan dan sayuran, sterilisasi ozon juga efektif dalam penurunan angka BOD dan COD pada limbah cair. Penurunan COD dan BOD yang terjadi semakin kecil seiring penambahan lama waktu proses ozonisasi, karena dengan semakin lama maka proses pembentukan $\mathrm{O}_{2}$ akan semakin banyak dan dengan sendiringa akan berpengaruh pada penurunan angka COD dan BOD. ${ }^{10}$ Penurunan kadar BOD, COD, TSS dan fosfat secara signifikan terjadi dari waktu ozonisasi 5 menit hingga 20 menit pada limbah rumah sakit, dan semakin banyak ozon diberikan ke dalam larutan limbah maka akan semakin banyak flok yang terbentuk sehingga flok-flok ini akan menyerap koloid-koloid dalam limbah dan menyebabkan kadar TSS dalam limbah turun. ${ }^{11}$

Berdasarkan hasil penelitian bahwasannya sterilisasi ozon tidak cukup efektif dalam penurunan angka kuman udara ruangan, akan tetapi ada metode sterilisasi lain yaitu dengan menggunakan sinar UV dapat menurunkan angka bakteri kontaminan udara. Terdapat perbedaan jumlah koloni bakteri kontaminan udara sebelum dan sesudah sterilisasi ultraviolet di ruang operasi RSUD Banjarbaru. Sinar ultraviolet dapat menyebabkan mikroorganisme bakteri yang berada di udara atau yang berada dilapisan permukaan suatu benda yang terpapar sinar ultraviolet akan mati. ${ }^{12}$

\section{SIMPULAN DAN SARAN}

\section{A. Simpulan}

Berdasarkan penilitian diatas dapat disimpulkan bahwa: tidak ada pengaruh antara sterilisasi ozon dengan penurunan angka kuman udara di ruang rawat inap di RSU PKU Muhammadiyah Bantul tahun 2014.

\section{B. Saran} berikut:

Saran yang dapat diberikan kepada pihak-pihak terkait adalah sebagai

1) Pihak RSU PKU Muhammadiyah Bantul adalah: Pemilihan metode sterilisasi ruangan dilakukan dengan metode sterilisasi yang cocok dengan ruangan yaitu dengan sterilisasi ultraviolet.

2) Peneliti lain yaitu agar dilakukan penelitian lanjutan dengan penambahan sampel penelitian dan pemilihan metode yang berbeda yaitu sinar ultraviolet. 


\section{Daftar Pustaka}

1. Departemen kesehatan Republik Indonesia, Profil Kesehatan Indonesia 2008, Jakarta, 2009. Diunduh di website http://www.depkes.go.id.

2. Darmadi, Infeksi Nosokomial Problematika dan Pengendaliannya, Salemba Medika, Jakarta, 2008.

3. Keputusan Kementerian kesehatan, Standar Pelayanan Minimal Rumah Sakit. SK Menteri Kesehatan Republik Indonesia Nomor : 129/Menkes/SK/II/2008.

4. Ducel, G., Fabry, J., Nicolle, L., Prevention of hospital-acquiredinfections, A.practical guide, $2^{\text {nd }}$ editions, World Health Organization, Department of communicable disease, survailance and response, 2002. Available from: http://klikharry.wordpress.com/2006/12/21/infeksinosokomial/.(Accesed 21 Desember 2006).

5. Septiari, BB., Infeksi Nosokomial, Nuha Medika, Yogyakarta, 2012.

6. Adji, D., Zuliyanti., Larashanty, H., Perbandingan Efektivitas Sterilisasi Alkohol 70\%, Inframerah, Otoklaf dan Ozon Terhadap Pertumbuhan Bakteri Bacillus subtilis, Jurnal Sain Vet, vol/no: 25(1), pp. 17-24, 2007.

7. Hakan, K., Sedat, VY, Ozone Aplication in Fruit and Vegetable Processing, Food Reviews International, vol/no: 23(1), pp. 91-106, 2007.

8. Kowalski, WJ., Bahnfleth, WP., Whittam, TS., Bactericidal Effects of High Airborne Ozone Concentrations on Escherichia coli and Staphylococcus aureus, Ozone Science \& Engineering, vol. 20, pp. 205-221, 1998.

9. Nadhila, Andanis Z., Pengaruh Waktu Inkubasi dan dosis Ozon pada Disinfeksi Hama bakteri Xanthomo nasoryzae pvoryzae Dengan Kombinasi Proses Ozonasi dan Adsorpsi Dengan Zeolit alam, Skripsi, Departemen Teknik Kimia, Fakultas Teknik, Universitas Indonesia, 2012.

10. Purwadi, A., Usada, W., Suryadi, Isyuniarto., Rancang Bangun Ozonizer Jinjing dan Manfaatnya, Prosiding PPI Litdas Iptek Nuklir P3TM-Batan Yogyakarta, 8 Juli 2004.

11. Isyuniarto, A., Pengaruh Waktu Ozonisasi Terhadap Penurunan Kadar BOD, COD, TSS dan Fosfat pada Limbah Cair Rumah Sakit, Ganendra, vol/no: XII(1), pp. 45-49, 2009.

12. Putri, CS., Budiarti, LY., Pujianti, N., Jumlah Bakteri Kontaminan Udara Sebelum dan Sesudah Sterilisasi Ultraviolet di Ruang Operasi RSUD Banjarbaru, Karya Tulis IImiah, Fakultas Kedokteran Universitas Lambung Mangkurat, 2013. 